\title{
COULOMETRIC DETERMINATION OF METAL CARBONATES IN BATTERY ELECTRODES BY DESTRUCTIVE ANALYSIS
}

\author{
Steve Wharton, Naval Surface Warfare Center, Crane Division \\ Crane, IN 47522
}

\begin{abstract}
:
A gravimetric method of destructive analysis of silver-zinc and nickel-cadmium battery electrodes to determine carbonate composition has been standard practice for the past fifteen years. This method is tedious, requires large sample sizes, and lacks both accuracy and precision. An alternative coulometric method to determine carbonate compositions using an off-the-shelf commercial instrument was investigated and found to be superior. The coulometric instrument requires half the time, one-tenth the amount of sample, and is far more accurate and precise. The instrument also promises to be used in conjunction with thermogravimetric analysis for simultaneous analysis of silver-oxides and -carbonates. This paper will compare the gravimetric and coulometric methods and illustrate the greater accuracy obtainable with the new method in the analysis of silver-oxide electrodes.
\end{abstract}

\section{BACKGROUND:}

The Material Science Branch (Code 6098) at the Naval Surface Warfare Center, (NSWC) Crane Division performs primarily destructive analysis on many types of battery components. One analysis is the determination of metal carbonates present in metal/metal-oxide anodes and cathodes. The standard used for years has been a gravimetric method which acidically decomposes metal carbonates releasing their carbon dioxide $\left(\mathrm{CO}_{2}\right)$ in a closed system after which a purge gas carries the $\mathrm{CO}_{2}$ through a series of caustic solid traps for weight-gain-by-difference determination. The method for this determination, developed by NSWC over ten years ago, combines apparatus used for carbon analysis by direct combustion ${ }^{l}$ and gravimetry (Method II) ${ }^{2}$ but substitutes two Nesbitt ${ }^{3}$ bulbs in series, in place of one absorption bulb. This apparatus has come to be known as a

US Government work not protected by US copyright carbonate train. Both the method and the carbonate train however, are tedious in use because they require: a considerable number of purges to obtain a stable blank, approximately one-gram of electrode material for each sample, about forty minutes total time for duplicate sample assays including partial disassembly, and four weight determinations and weight-difference calculations for duplicate samples. In addition, the train is often affected by humidity during Summer months. These requirements combined make the gravimetric method lack precision and accuracy.

\section{INTRODUCTION:}

A replacement instrumental method has been sought for the last several years; a method which would be quicker, use less sample, require less data and data manipulation, and be more precise. Most standard analytical equipments available on the market were more precise, but still used a gravimetric method, and the best were available only from foreign sources. However, a domestic-made instrument was found in use locally which chemically trapped, and coulometrically titrated $\mathrm{CO}_{2}$ released from carbonate rocks. The instrument was called a carbon coulometer. Because the standard gravimetric method was deeply imbedded into several standard test procedures, the carbon coulometer had to be tested, qualified, and finally certified for use in the standard test programs.

\section{DISCUSSION:}

The carbon coulometer is pictured in Figure I (right side) and consists mainly of the electronic instrument (metal chassis with digital displays) and the cell (glass beaker with side-arm). The cell interfaces the instrument through the two (red and black) wire leads shown in the figure. In operation, $\mathrm{CO}_{2}$ is purged into the larger cathode side of the 


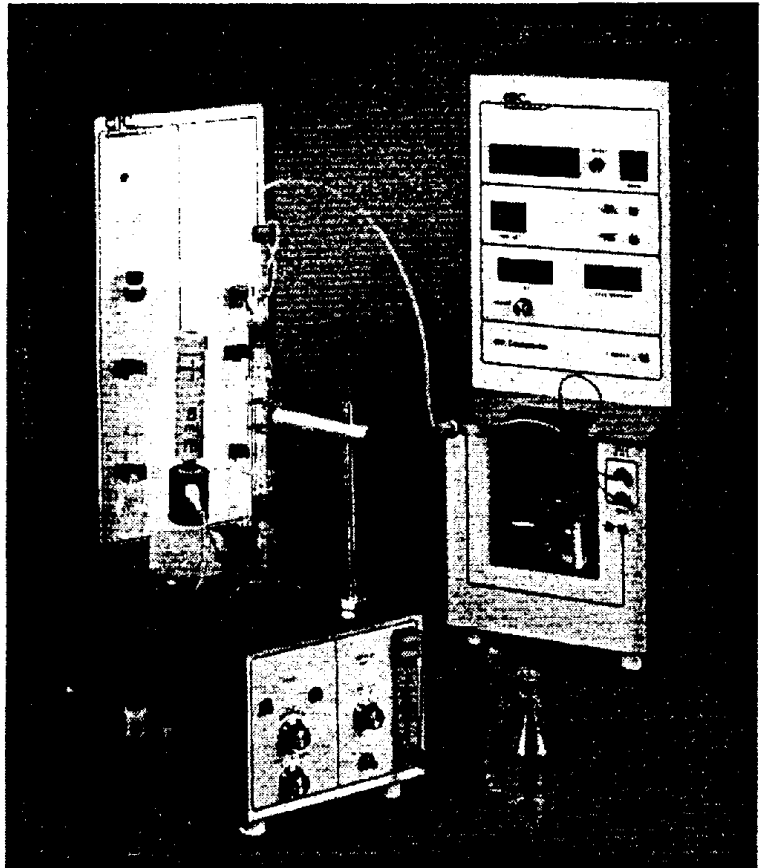

Figure 1. Coulometer \& Acidification Module

cell by the carrier gas, absorbed into the cathode solution, and coulometrically titrated by hydroxyl ion $\left(\mathrm{OH}^{-}\right)$electrochemically generated on the cathode by oxidation of the silver electrode in the smaller, anode side of the cell. The instrument controls the rate of titration according to the rate of $\mathrm{CO}_{2}$ absorption using a color indicator and an optical sensor, and essentially counts the electronic equivalents of $\mathrm{CO}_{2}$ according to the time-integrated current required for titration to an optical endpoint. $\mathrm{CO}_{2}$ can be liberated from the metal/metal-oxide electrode matrix either by acidification or by heating a known weight of the sample. The acidification module, purchased for use with the carbon coulometer, is pictured with it in Figure I (left side). The acidification module interfaces the instrument through the small tubing used to carry the acid from the module into the cell. In operation, the sample is weighed and introduced into any of four standard-sized flasks (shown in the figure) and attached to the module. Acid is injected into the flask from the reservoir shown releasing the $\mathrm{CO}_{2}$ into the carrier gas which can be pre- and post-scrubbed (air or any other gas) of other undesirable gases. The carbon coulometer can be operated in a semi-automatic mode using a personal computer interfaced through an RS232 connector on the instrument. The complete instrument and figures are provided by UIC, Inc. of Joliet, $\mathbb{I}$.

Qualification and certification testing of the coulometer was planned to include assays of both certified carbonate standards and unknowns compared to assays of the same materials using the carbonate train. Because the coulometer is designed to accept $\mathrm{CO}_{2}$ liberated by either acidification or heating of samples, an experiment was also planned to test the coulometer in series with a thermogravimetric analyzer (TGA) currently being used for determination of silver oxides. The coulometer was placed in series, down stream of the TGA where off-gasses could be scrubbed and assayed for $\mathrm{CO}_{2}$ content. The objective of this experiment was to determine if the coulometer and TGA could be used together for simultaneous determination of silver-oxides and -carbonates.

\section{RESULTS:}

Table I compares the results of multiple assays of standard silver carbonate used for acceptance qualification of the coulometer.

Table I: Accrued Data Summary

\begin{tabular}{|c|c|c|c|}
\hline \multicolumn{2}{|c|}{ Coulometer Statistics: } & \multicolumn{2}{|c|}{ Train Statistics: } \\
\hline AVG: & 99.43 & AVG: & 103.96 \\
\hline STD: & 0.83 & STD: & 3.63 \\
\hline Range: & 97.76 to 101.09 & Range: & 96.70 to 111.22 \\
\hline \multicolumn{2}{|c|}{ Certified Assay: $99.5 \%$} & \multicolumn{2}{|c|}{ Certified Assay: $99.5 \%$} \\
\hline Error: & $-0.07 \%$ absolute & Error: & $4.46 \%$ absolute \\
\hline Data Qty: & 10 & Data Qty: & 10 \\
\hline Assay & Data & Assay & Data \\
\hline Dates: & $\% \mathrm{Ag}_{2} \mathrm{CO}_{3}$ & Dates: & $\% \mathrm{Ag}_{2} \mathrm{CO}_{3}$ \\
\hline 07-Dec-93 & 97.75 & 15-Dec-93 & 101.51 \\
\hline 16-Dec-93 & 99.73 & 15-Dec-93 & 98.11 \\
\hline 16-Dec-93 & 99.90 & 17-Dec-93 & 108.85 \\
\hline 08-Feb-94 & 98.10 & 17-Dec-93 & 107.42 \\
\hline $09-$ Feb-94 & 99.61 & 17-Dec-93 & 99.69 \\
\hline 10-Feb-94 & 100.60 & 17-Dec-93 & 102.01 \\
\hline 03-Mar-94 & 99.48 & 08-Feb-94 & 104.52 \\
\hline 01-Apr-94 & 99.42 & 08-Feb-94 & 102.02 \\
\hline 13-May-94 & 100.22 & 08-Feb-94 & 108.44 \\
\hline 29-Jun-94 & 99.45 & $08-F e b-94$ & 107.04 \\
\hline
\end{tabular}

The data show that the average assay of the standard (AVG) by the coulometer $(99.43 \%)$ was 
much closer to the certified assay $(99.5 \%)$ than the train $(103.96 \%)$, and that the scatter or standard deviation (STD) of the coulometer data $(0.83 \%)$ was considerably lower than for the train $(3.63 \%)$ for the ten data points. These results show that the coulometer is able to produce a more accurate assay than the train. Table II compares the results of duplicate assays of standard silver carbonate using both the coulometer and the train. The data show that the average scatter in duplicate data (Average Standard Deviation) is much less using the coulometer $(0.25 \%)$ than using the train $(1.07 \%)$.

Table II. Duplicate Standard Assays

Sample: $99.5 \% \mathrm{Ag}_{2} \mathrm{CO}_{3}$ Standard

\begin{tabular}{lrrrrr} 
Test Date & \multicolumn{1}{c}{$\begin{array}{c}\text { Assay } \\
\text { Train Method }\end{array}$} & $\begin{array}{c}\text { Second } \\
\text { Assay }\end{array}$ & Average & $\begin{array}{c}\text { Standard } \\
\text { Deviation }\end{array}$ & $\begin{array}{c}\text { Average } \\
\text { Standard } \\
\text { Deviation }\end{array}$ \\
\hline 15-Dec-93 & 101.51 & 98.11 & $99.81 \%$ & $1.70 \%$ & \\
17-Dec-93 & 108.85 & 107.42 & $108.14 \%$ & $0.72 \%$ & \\
17-Dec-93 & 99.69 & 102.01 & $100.85 \%$ & $1.16 \%$ & \\
08-Feb-94 & 104.52 & 102.02 & $103.27 \%$ & $1.25 \%$ & \\
03-Feb-94 & 108.44 & 107.44 & $107.94 \%$ & $0.50 \%$ & $1.07 \%$ \\
Coulometer & Method & & & & \\
16-Dec-93 & 99.73 & 99.90 & $99.82 \%$ & $0.09 \%$ & \\
08-Feb-94 & 98.10 & 98.02 & $98.06 \%$ & $0.04 \%$ & \\
10-Feb-94 & 100.60 & 99.60 & $100.10 \%$ & $0.50 \%$ & \\
03-Mar-94 & 99.48 & 98.64 & $99.06 \%$ & $0.42 \%$ & \\
01-Apr-94 & 99.47 & 99.04 & $99.26 \%$ & $0.22 \%$ & $0.25 \%$ \\
\hline
\end{tabular}

These results show that the coulometer, proven more accurate in Table $\mathrm{I}$, is also more precise using only duplicate assays. Table III compares the results of duplicate assays of silver electrode material of unknown composition using both the coulometer and the train.

Table III. Duplicate Silver Electrode Assays Sample: Silver Electrode Unknowns

\begin{tabular}{lrrrrr}
\hline \multicolumn{2}{c}{ Train Method } & & & & \\
Test Date & $\begin{array}{c}\text { First } \\
\text { Assay }\end{array}$ & $\begin{array}{c}\text { Second } \\
\text { Assay }\end{array}$ & Average & $\begin{array}{c}\text { Standard } \\
\text { Deviation }\end{array}$ & $\begin{array}{c}\text { Average } \\
\text { Standard } \\
\text { Deviation }\end{array}$ \\
16-Apr-93 & 8.06 & 7.75 & $7.90 \%$ & $0.15 \%$ & \\
& 9.02 & 9.03 & $9.03 \%$ & $0.01 \%$ & \\
& 8.78 & 9.32 & $8.90 \%$ & $0.42 \%$ & \\
& 9.83 & 9.34 & $9.59 \%$ & $0.25 \%$ & \\
$21-$ Apr-93 & 9.31 & 9.36 & $9.37 \%$ & $0.03 \%$ & $0.17 \%$ \\
& 9.03 & 9.61 & $9.32 \%$ & $0.29 \%$ & \\
& 5.78 & 6.81 & $6.30 \%$ & $0.52 \%$ & \\
& 17.49 & 17.24 & $17.37 \%$ & $0.13 \%$ & \\
\hline
\end{tabular}

\begin{tabular}{crrrrr} 
& 15.42 & 15.47 & $15.45 \%$ & $0.03 \%$ & \\
$\begin{array}{c}\text { Coulometer } \\
\text { Method }\end{array}$ & 8.45 & 8.66 & $8.56 \%$ & $0.11 \%$ & $0.21 \%$ \\
16-Feb-94 & 5.38 & 5.13 & $5.26 \%$ & $0.13 \%$ & \\
& 4.81 & 4.87 & $4.84 \%$ & $0.03 \%$ & \\
& 4.16 & 4.20 & $4.18 \%$ & $0.02 \%$ & \\
& 4.72 & 4.66 & $4.69 \%$ & $0.03 \%$ & $0.05 \%$ \\
$17-$ Feb-94 & 6.42 & 6.36 & $6.39 \%$ & $0.03 \%$ & \\
& 9.15 & 9.10 & $9.13 \%$ & $0.03 \%$ & \\
& 5.78 & 5.74 & $5.76 \%$ & $0.02 \%$ & \\
& 5.30 & 5.37 & $5.34 \%$ & $0.04 \%$ & \\
& 8.15 & 8.19 & $8.17 \%$ & $0.02 \%$ & $0.03 \%$ \\
\hline
\end{tabular}

The data show that the average scatter is much less using the coulometer $(0.05 \%$ and $0.03 \%)$ than for the train $(0.17 \%$ and $0.21 \%)$. These results show that the coulometer is also more precise using only duplicate assays of unknown silver electrode material. Table IV compares the results of duplicate assays of zinc electrode material of unknown composition using both the coulometer and the train.

Table IV. Duplicate Zinc Electrode Unknowns Sample: Zinc Electrode Unknowns

\begin{tabular}{|c|c|c|c|c|c|}
\hline Test Date & $\begin{array}{l}\text { First } \\
\text { Assay }\end{array}$ & $\begin{array}{l}\text { Second } \\
\text { Assay }\end{array}$ & Average & $\begin{array}{c}\text { Standard } \\
\text { Deviation }\end{array}$ & $\begin{array}{l}\text { Average } \\
\text { Standard } \\
\text { Deviation }\end{array}$ \\
\hline \multicolumn{6}{|c|}{ Train Method } \\
\hline \multirow[t]{5}{*}{ 18-Mar-93 } & 0.48 & 0.28 & 0.38 & 0.10 & \\
\hline & 3.37 & 3.51 & 3.44 & 0.07 & \\
\hline & 2.24 & 2.48 & 2.63 & 0.12 & \\
\hline & 0.94 & 1.09 & 1.01 & 0.08 & \\
\hline & 1.57 & 1.23 & 1.40 & 0.17 & $0.11 \%$ \\
\hline \multirow[t]{5}{*}{ 12-Apr-93 } & 1.66 & 1.57 & 1.62 & 0.05 & \\
\hline & 1.28 & 1.96 & 1.62 & 0.34 & \\
\hline & 0.30 & 0.61 & 0.46 & 0.16 & \\
\hline & 4.92 & 4.63 & 4.78 & 0.15 & \\
\hline & 2.20 & 1.88 & 2.04 & 0.16 & $0.17 \%$ \\
\hline \multicolumn{6}{|c|}{ Coulometer Method } \\
\hline \multirow[t]{5}{*}{ 04-Mar-93 } & 0.04 & 0.03 & 0.03 & 0.00 & \\
\hline & 0.03 & 0.03 & 0.03 & 0.00 & \\
\hline & 0.11 & 0.06 & 0.09 & 0.02 & \\
\hline & 0.06 & 0.05 & 0.06 & 0.00 & \\
\hline & 0.03 & 0.02 & 0.03 & 0.00 & $0.01 \%$ \\
\hline \multirow[t]{5}{*}{ 02-Mar-94 } & 0.25 & 0.26 & 0.26 & 0.01 & \\
\hline & 0.04 & 0.05 & 0.04 & 0.01 & \\
\hline & 0.05 & 0.05 & 0.05 & 0.00 & \\
\hline & 0.05 & 0.05 & 0.05 & 0.00 & \\
\hline & 0.06 & 0.08 & 0.07 & 0.01 & $0.00 \%$ \\
\hline
\end{tabular}

The data show that the average scatter is much less using the coulometer $(0.01 \%$ and $0.00 \%)$ than for the train $(0.11 \%$ and $0.17 \%)$. These results show that the coulometer is also more precise using only 
duplicate assays of unknown zinc electrode material. Table $\mathrm{V}$ compares the results using acidic $\mathrm{CO}_{2}$ liberation to thermal (TGA) liberation for standard silver carbonate and an unknown containing a high amount of silver carbonate. The results for the standard show that acid liberation is acceptably accurate, although more scattered than expected $(99.53 \% \pm 1.56 \%)$; but that the result using thermal liberation is unacceptably low and considerably more scattered $(87.96 \% \pm 6.8 \%)$. This last result is believed to have occurred because the end-point criterion used by the coulometer caused it to prolong the determination beyond the normal 30-minute TGA run time resulting in an erroneous over-adjustment of the reagent blank value. This suspicion appears to be substantiated by the results for the high carbonate unknown, where both acidic and thermal liberation produced acceptable values $(19.58 \% \pm 0.28$ and $18.92 \% \pm 0.54$ respectively). These limited results are significant because they appear to confirm the feasibility of simultaneous thermal analysis of metal oxides and coulometric analysis of metal carbonates with the introduction of the carbon coulometer. Graphs I and II show the combined results of thermal analysis of silver oxides coupled with simultaneous coulometric analysis of evolved $\mathrm{CO}_{2}$. In both graphs the remaining weight of the sample material is graphed as the first dependent variable versus the independent sample temperature.

Table V. Coulometer Assays Using Acid \& Thermal Decomposition

\begin{tabular}{|c|c|c|c|}
\hline \multicolumn{4}{|c|}{ Sample: Silver Carbonate Standard } \\
\hline \multicolumn{2}{|c|}{ Acid Decomposition } & \multicolumn{2}{|c|}{ Thermal Decomposition } \\
\hline AVG: & 99.53 & AVG: & 87.96 \\
\hline STD: & 0.78 & STD: & 3.40 \\
\hline Range: & 97.98 to 101.08 & Range: & 81.15 to 94.76 \\
\hline \multicolumn{2}{|c|}{ Certified Assay: $99.5 \%$} & \multicolumn{2}{|c|}{ Certified Assay: $99.5 \%$} \\
\hline Enror: & $0.03 \%$ absolute & Error: & $-11.55 \%$ absolute \\
\hline \multirow[t]{2}{*}{ Data Qty: } & 4 & Data Qty: & 4 \\
\hline & Standard & & Standard \\
\hline Elapsed & $\% \mathrm{Ag}_{2} \mathrm{CO}_{3}$ & Elapsed & $\% \mathrm{Ag}_{2} \mathrm{CO}_{3}$ \\
\hline Time(min) & Data & Time(min) & Data \\
\hline 6 & 99.50 & 47 & 82.90 \\
\hline 9 & 99.60 & 60 & 88.91 \\
\hline 6 & 98.41 & 60 & 87.62 \\
\hline 6 & 100.60 & 35 & 92.39 \\
\hline
\end{tabular}

\begin{tabular}{lrlr} 
Sample: Silver Electrode Unknown & & \\
Acid Decomposition & & Thermal Decomposition & \\
AVG: & 19.58 & AVG: & 18.92 \\
STD: & 0.14 & STD: & 0.29 \\
Range: & 19.29 to 19.87 & Range: & 18.34 to 19.49 \\
Data Qty: & 5 & Data Qty: & 4 \\
& & & \\
& Unknown & & Unknown \\
Elapsed & \%Ag, CO $_{3}$ & Elapsed & \% Ag $_{2} \mathrm{CO}_{3}$ \\
Time(min) & Data & Time(min) & Data \\
6 & 19.68 & 28 & 18.85 \\
6 & 19.49 & 28 & 18.76 \\
6 & 19.45 & 30 & 18.6 \\
7 & 19.45 & 30 & 19.4 \\
7 & 19.81 & & \\
\hline
\end{tabular}

These are typical TGA plots of silver cathode materials. In Graph I, $\mathrm{CO}_{2}$ evolution rate is plotted as the second dependent variable compared to the TGA plot. Graph I clearly shows that there are two peaks in thermal $\mathrm{CO}_{2}$ evolution: the first at about $230^{\circ} \mathrm{C}$, and the second at about $360^{\circ} \mathrm{C}$. In Graph II the cumulative total $\mathrm{CO}_{2}$ evolved is plotted as the second dependent variable compared to the TGA plot. Graph II clearly shows that at $230^{\circ} \mathrm{C}$ only about $52 \%$ of the total $\mathrm{CO}_{2}$ has been evolved, and that at $360^{\circ} \mathrm{C}$ (the second evolution peak), about $95 \%$ of the total $\mathrm{CO}_{2}$ is evolved.

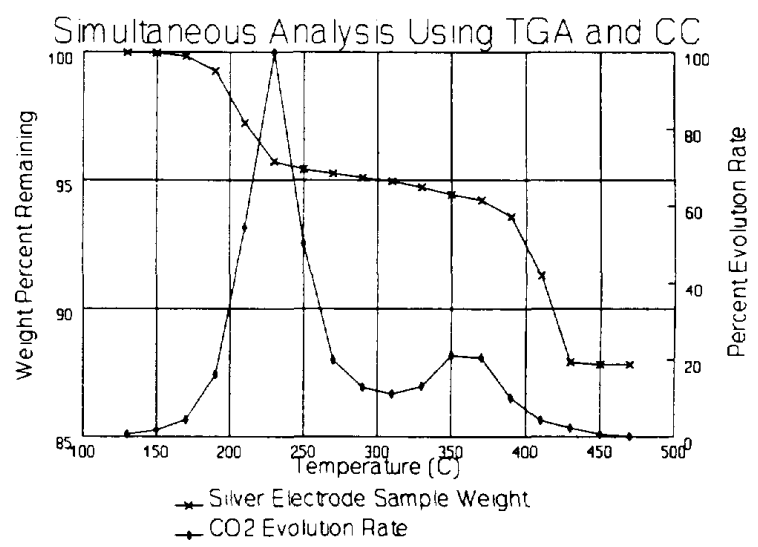

Graph I. $\mathrm{CO}_{2}$ Evolution Rate 


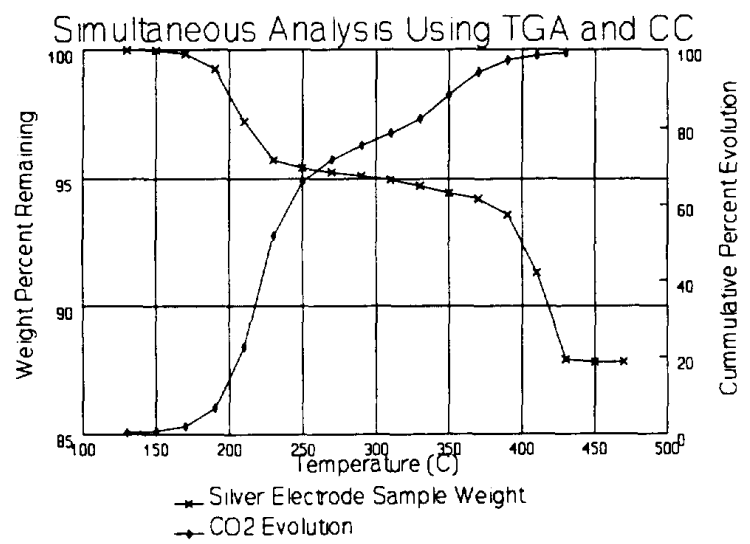

Graph II. Cumulative $\mathrm{CO}_{2}$ Evolution

These data corroborate Dallek et. al. ${ }^{4}$ findings which suggest that two forms of $\mathrm{Ag}_{2} \mathrm{CO}_{3}$ may be present, and that $\mathrm{CO}_{2}$ evolution is nearly completed at $360^{\circ} \mathrm{C}$. The results are significant because the algebraic equations used to calculate the relative amounts of silver (I and II) oxides present in sample are valid only under the conditions that: $\mathrm{CO}_{2}$ evolution is completed at $360^{\circ} \mathrm{C}$, and that an accurate, independent method to determine $\mathrm{Ag}_{2} \mathrm{CO}_{3}$ is employed.

\section{CONCLUSIONS:}

The results comparing the old method carbonate train to the new method carbon coulometer show that the coulometer is more accurate and precise both for multiple samples assayed over an extended period of time, and for duplicate samples measured successively. Also, when used by itself, the coulometer assays duplicate samples in half the time (15-minutes) compared to duplicates assayed using the train. The coulometer also requires only about one-tenth the amount of sample $(0.1 \mathrm{~g})$ as the train. Therefore, the coulometer provides increased accuracy and precision while reducing work time involved in standard test programs. Last, simultaneous thermal and coulometric analyses have proven not only feasible, but also capable of determining more accurately the temperature dependent rate of $\mathrm{CO}_{2}$ evolution during TGA assays of silver cathode materials.

\section{FUTURE WORK:}

The method using simultaneously TGA and coulometric analyses is still under investigation.

\section{REFERENCES:}

1. Standard Methods of Chemical Analysis, 6th Ed, Vol I-The Elements, N.H. Furman PhD, Editor, Van Nostrand Co, NY, March 1962, p.288.

2. Ibid, p.300.

3. Chemical Analysis of Iron and Steel, G. Lundell, J. Hoffman, and H. Bright, John Wiley and Sons, NY, 1931, p.169.

4. Thermogravimetrically-Evolved Gas Analysis of Silver Oxide Cathode Material, S. Dallek, B. Larrick, and W. Parkhurst, J. Electrochem. Soc.: Electrochemical Science and Technology, August 1984, p.1739. 